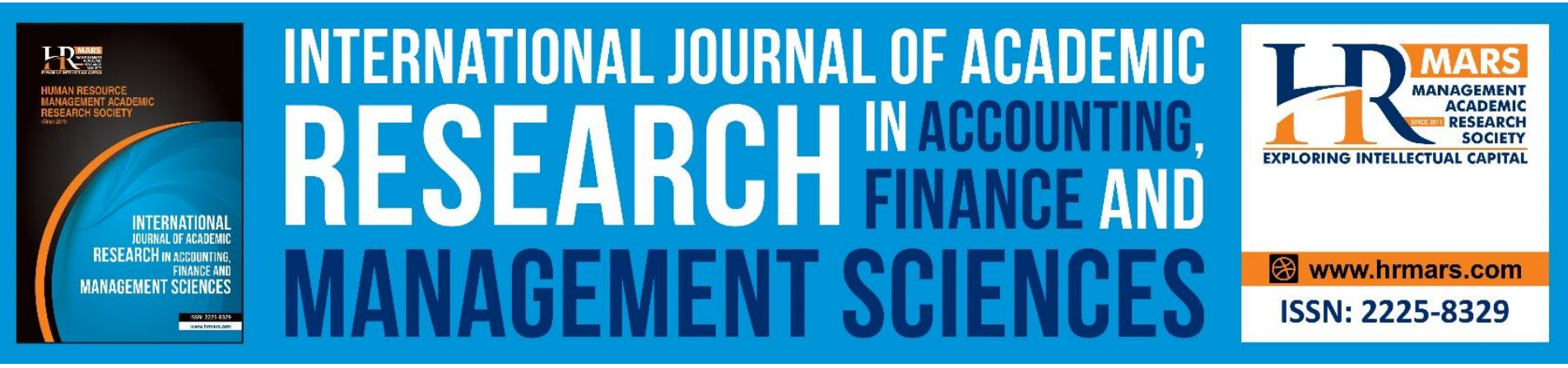

\title{
The Influence of Service Marketing Mix on Customer Loyalty towards Islamic Banks: Evidence from Jordan
}

\author{
Mohammad Alafeef
}

To Link this Article: http://dx.doi.org/10.6007/IJARAFMS/v10-i3/7862

DOI:10.6007/IJARAFMS/v10-i3/7862

Received: 14 June 2020, Revised: 20 July 2020, Accepted: 24 August 2020

Published Online: 02 September 2020

In-Text Citation: (Alafeef, 2020)

To Cite this Article: Alafeef, M. (2020). The Influence of Service Marketing Mix on Customer Loyalty towards Islamic Banks: Evidence from Jordan. International Journal of Academic Research in Accounting, Finance and Management Sciences. 10(3), 239-255.

\section{Copyright: @ 2020 The Author(s)}

Published by Human Resource Management Academic Research Society (www.hrmars.com)

This article is published under the Creative Commons Attribution (CC BY 4.0) license. Anyone may reproduce, distribute, translate and create derivative works of this article (for both commercial and non-commercial purposes), subject to full attribution to the original publication and authors. The full terms of this license may be seen

at: $\underline{\text { http://creativecommons.org/licences/by/4.0/legalcode }}$

\section{Vol. 10, No. 3, 2020, Pg. 239 - 255}




\title{
The Influence of Service Marketing Mix on Customer Loyalty towards Islamic Banks: Evidence from Jordan
}

\author{
Mohammad Alafeef \\ Department of Finance and Banking, Faculty of Economics and Administrative Sciences, Al Albayt \\ University, Jordan
}

\begin{abstract}
This study aimed to conduct an analysis of the influence of service marketing mix on customer loyalty, with customer satisfaction as the mediating variable in the context of Islamic banks in Jordan. Banks generally require catering to distinct needs and preferences of customers in order to sustain their long-term relationship. The study collected the required data from 344 respondents using a structured questionnaire, with the sample obtained through convenience sampling approach. Based on the research results, all the elements of service marketing mix, namely price, product, place, promotion, process, people and physical evidence significantly and positively affected customer satisfaction and customer loyalty. This study contributes to the Jordanian Islamic banks knowledge and information concerning the marketing mix strategies that they can adopt in order to sustain and maintain long-term customer relationships. The study supported the importance of customer satisfaction for the creation of customer loyalty. The study findings have implications to literature and practice when it comes to understanding the marketing mix pattern, customer satisfaction and customer loyalty relationship.
\end{abstract}

Keywords: Customer Loyalty, Service Marketing Mix, Customer Satisfaction, Jordanian Islamic Banks.

\section{Introduction}

The development of banking has gone through leaps and bounds in the current world and such development may be attributed to the increasing technology growth and development as well as the development in information, machine and communication technology. Consequently, the developments affect community behavior and in the face of technology, community is enabled to access information, specifically when it comes to banking information, and this holds true for Jordan. Specifically, Jordan's banking sector has undergone several improvements because of several factors, with the top being marketing. Effective and suitable marketing has a positive impact on the industrial actors, including banks. Marketing in banks refers to the creation and exchange of the bank's product/service intended to bring about customer satisfaction.

Generally speaking organizations lay emphasis on facilitating stability and success in their relationships with customers in the current environment rife with dynamism and numerous challenges. Marketing has paved an evolutionary path where the concern does not merely stem from new customers - but acquiring new customers, maintaining current customers and establishing long- 
INTERNATIONAL JOURNAL OF ACADEMIC RESEARCH IN ACCOUNTING, FINANCE AND MANAGEMENT SCIENCES

Vol. 10, No. 3, 2020, E-ISSN: 2225-8329 @ 2020 HRMARS

term relationship with both (Chaffey, 2019). As for the requirement of customer orientation in the current business management environment, customer is deemed as the primary business process and performance source, upon which maintain productive relationships are based on as well as attracting new customers (Mandal, 2020). Moreover, in the present business market, rapid development has been documented because of the large dependence on e-methods and of the dynamic competition brought on by new banking institutions providing similar services/methods offered through competitive prices - this makes the customer's transfer from one banking institution to the next easy. This is sometimes brought on by the imbalances or lack of quality in banks, urging customers to change from one bank to another and as such, banks need to focus on the marketing mix of their services and its link with customer behavior in order to enhance their competitive advantage through new products/services, and eventually capture customer loyalty. The Central Bank statistics in their website indicate that the Jordanian banking sector comprises of 24 banks, from which 4 are Islamic banks, the latter of which are the Jordan Islamic Bank, Islamic International Arab Bank, Safwa Islamic Bank and Al-Rajhi Bank (Central_Bank_of_Jordan, 2019). This study shows that there is a lack of awareness in the literature about the service marketing mix on customer loyalty. Therefore, this study aims to establish and empirically analyze a research model of the service marketing mix from the perspective of customer loyalty, in addition to exploring the service marketing mix. In detail, this study attends to explore the service marketing mix in the Jordanian Islamic banks.

The remaining part of the current work is organized in the following sections; Section 2 presents a review of relevant literature and this is followed by Section 3 that explains the development of the study framework. Section 4 contains the research methodology adopted and Section 5 provides the obtained findings. Lastly, Section 6 provides the conclusion of the study.

\section{Literature Review}

The Islamic finance industry has been estimated by Standard \& Poor's report in September 2012 to display 20\% growth each year from 2011 until 2015. There are over 420 Islamic financial institutions in 75 nations (Muslim and Non-Muslim) all over the globe.

In Jordan, Islamic banking sector was introduced 30 years ago with the inauguration of the pioneering Islamic Bank in the country in 1978 called Jordan Islamic Bank for Finance Investment. This was followed by the proliferation of Islamic banks in the country, with extended branches including the Islamic International Arab Bank (IIAB) in 1995 and Jordan Dubai Islamic Bank in 2010. By 2011, the first foreign Islamic Bank was established in the country in the form of Al-Rajhi Bank. In general, Islamic banks in Jordan are capable of achieving positive growth in the long-run as they concentrate on strategies that are created for the attraction of Muslim and Non-Muslim clients, adopting marketing activities to promote awareness concerning the services offered and supporting and building on customer-relationship (Di Bella \& Al-Fayoumi, 2016).

Relative to the countries in the region, the Islamic banking industry in Jordan is still in its early stage, and financial service market growth has been notable although the industry has limited concentration and dimension. However, the good performance and future prospects of Jordanian Islamic banks does not overshadow the challenges that such banks face (local and global) that could prevent their growth potential.

Moreover, the service sector is one of the major contributing sectors in the country, with banks playing a key role in the countries' economic growth and development. In other words, banks have 
INTERNATIONAL JOURNAL OF ACADEMIC RESEARCH IN ACCOUNTING, FINANCE AND

MANAGEMENT SCIENCES

Vol. 10, No. 3, 2020, E-ISSN: 2225-8329 ๑ 2020 HRMARS

the ability to impact economic growth via customer satisfaction and the promotion of awareness about savings and capital accumulation through manufacturing and consumption industries (Othman et al., 2018). Hence, it is pertinent for banks to direct and implement establishing systems for customer satisfaction through clear factors that impact the same (Supanun, 2019). The present paper aims to resolve the question as to the possibility of the presence of a significant relationship between banks marketing max and customer satisfaction. The next section reviews relevant and related literature.

\section{Marketing Mix}

The marketing mix concept was brought up by Neil Borden in his AMA presidential address in 1953, adopting the idea from James Culliton, who first referred to the business executive as consisting of a combination of different elements. Marketing mix is a term that refers to a combination of elements that is used to pursue specific market responses (Van Waterschoot \& Van den Bulte, 1992).

More recently, Yelkur (2000) described the services marketing mix as a measurement of quality purpose of services, as services have an intangible purpose. This was followed by Booms and Bitner's (1980) 3Ps, which are people, physical environment and process to the original marketing mix (4Ps). In other words, there are 7Ps to the services sector, which are utilized to achieve customer satisfaction and they are; product, price, place, promotion, people, physical environment and process (Gibbs, Pashiardis \& Ivy, 2008).

The application of marketing mix practices in organizations can assist in achieving objectives, making sales and increasing profitability (Othman, Harun \& Nazeer, 2018), using the 7Ps of the service marketing mix (price, product, promotion, place, process, people and physical evidence).

The examination and insight into the marketing mix elements can enable businesses and organizations to influence their current customers to do business with them and obtain their loyalty. This approach may be adopted by the banking industry to urge and convince clients to purchase and re-purchase financial services from them as opposed to from their rivals.

\section{Product}

Product is a thing that can be presented in the market for the purpose of acquiring, considering and using on the part of the consumers to satisfy needs (Kotler, Burton, Deans, Brown \& Armstrong, 2015).

In the realm of financial services, products/services offered by banking institutions are those that facilitate various financial transaction and activities including loans, insurance, credit cards, investment opportunities and money management, information provision on the stock market and market trends.

Banks offer standardized or close to standardized products to customers, with the need to increase customized products/services in order to cater to individual customer's requirements (Sathiyavany \& Shivany, 2018). With regards to financial services complexity, owing to high risk and involvement, accessing a trusted service provider that offers products/service value is of utmost importance (Kushwaha \& Agrawal, 2015).

In literature dedicated to bank marketing, banking services have been deemed to be mainly focused on products and realizing organizational objectives through product profitability (Kushwaha \& Agrawal, 2015). Hence, the service product development is crucial in providing beneficial packages in 
INTERNATIONAL JOURNAL OF ACADEMIC RESEARCH IN ACCOUNTING, FINANCE AND

MANAGEMENT SCIENCES

Vol. 10, No. 3, 2020, E-ISSN: 2225-8329 ๑ 2020 HRMARS

the form of offerings in the perspectives of customers (Payne, Frow \& Eggert, 2017) and thus, this study proposes the following hypothesis for testing;

H1: Product is positively associated with customer satisfaction.

\section{Price}

One of the communication approach used by marketer with customers is price and it is considered as revenue-oriented approach that is part of the marketing mix. Mohammad (2015) stated that price was defined by Winkler as the amount of money sacrificed for obtaining a thing. In Varki and Colgate's (2001) examination of customer perception of value (price) in the U.S. and New Zealand banking industry, price perceptions were found to have a direct relationship with customer satisfaction.

Prices may be deemed as attributes requiring standardization to obtain specific services/products types (Kushwaha \& Agrawal, 2015). In this regard, the service price has to be suitable for the customer to out the offered service. Additionally, pricing decisions have a key role in service marketing strategies, with fixed price being related to the sales targets, product life cycles and market share (AMEUR, Keltouma \& SOUAR, 2015).

According to Wang, Hu and Liu (2017), customers in the current era are more price-sensitive than before, which explains why more and more marketing authors have focused on pricing as a major determinant for customer related variables (attraction, satisfaction, retention and loyalty) (Kushwaha \& Agrawal, 2015) and thus, this study proposes that;

H2: Price is positively associated with customer satisfaction.

\section{Promotion}

One of the fundamental marketing mix elements in banks is promotion, playing a key role in making customers aware of the offered services and convincing their purchase of them and the advantages of doing so, and the gratifications that can be realized from it. Subsequently, this cements their decisions to deal with the bank in the future.

Promotion refers to the use of banks of efforts and methods (personal and non-personal) to get customers to be attracted to their services, to explain the services benefits and characteristics and in sum, to deal with the bank.

Hence, promotional activities carried out via community relations, event management, media promotion and corporate entity initiatives are significant and should be adopted. The entire promotional mix techniques and strategies are utilized to urge people to conduct business with the firm (Hoffman \& Birnbirch, 2012). Market research studies in banking were carried out by Kushwaha and Agrawal (2015), wherein which they evaluated the advertising and publicity and image of the bank in the people's perception. Promotion represents the overall perception of the customer concerning the bank. Thus, this study proposes the following hypothesis to be tested;

H3: Promotion is positive associated with customer satisfaction.

\section{Place}

This element represents the decisions and activities of the bank that is directed towards making services accessible to customers and the distribution channel reflects the bank-customer relationship.

In addition, banking distribution concept is akin to the distribution of any general goods/services but with more challenges owing to the nature and characteristics of services. In this regard, the 
INTERNATIONAL JOURNAL OF ACADEMIC RESEARCH IN ACCOUNTING, FINANCE AND

MANAGEMENT SCIENCES

Vol. 10, No. 3, 2020, E-ISSN: 2225-8329 ๔ 2020 HRMARS

distribution channel delivers the service and assists in maintaining current clients and attracting new ones. Owomoyela, Oyeniyi and Ola (2013) referred to place as a specific location where the customer can receive the product or service offered.

The banking industry can enhance customer service, attract new customers and remain competitive in the market by establishing service delivery channels that are consistent and complementary like the physical location of the bank, its opening hours, distance to reach the bank, parking areas, and availability of ATMs (Kushwaha \& Agrawal, 2015), the extended branches and ATM locations. Thus, the study proposes that;

H4: Place is positively associated with customer satisfaction.

\section{People}

Some authors described people as an element of marketing mix as employees that play a role in generating and selling the service, representing a certain work function to improve bank image. Generally speaking, banking service customers need to be presented an intellectual image to form their opinions.

In a related study, Judd (1987) brought forward that employees form a certain element of the marketing mix and an integral part of the marketing strategy. Employee management in light of defined, customer-related roles can boost the competitive advantage of the organization that could distinguish it from its rivals.

Service employee in the banking field is the major contact point for the customers and the latter's perceptions of the employee's service performance is significant in evaluating the quality of service provided. This covers the employee's attitude, behavior, expertise, confidence, courtesy and inclination towards assisting customers (Fukey, Issac, Balasubramanian \& Jaykumar, 2014). Added to the above, customer-oriented employees that concentrate on providing personal attention, care, assistance, politeness and prompt service have a significant contribution to the bank-customer relationship (Kushwaha \& Agrawal, 2015) and as such, this study proposes the following hypothesis; H5: People are positively associated with customer satisfaction.

\section{Process}

In order to provide quality services, processes are a must and because services have an intangible nature, processes are crucial for the establishment of standards. Mapping processes can provide quality services to the target segment.

Processes refer to procedures including the activities flow that bring about the services/goods provision and the steps implementation to deliver service to the customers. This provides a set of evidence suitable with controlling/dealing with the provided good/service and it a guide to the customer concerning the same.

In the banking realm, the processes need to be smooth sailing, fast and accurate and customeroriented and customer-friendly. In fact, businesses have shifted to e-channels or e-banking when providing their services. Majority of researchers contended that e-banking accessibility from any location, at any time is a crucial factor for bank customers. Customer satisfaction in banks largely depends on the service delivery process (Shamah, 2013). Delivery ease of use and expediency also play a role as service quality dimensions for online financial services. Other aspects in e-banking services include service convenience, accuracy and ease of use (Kushwaha \& Agrawal, 2015). This study proposes the following hypothesis for testing; 
INTERNATIONAL JOURNAL OF ACADEMIC RESEARCH IN ACCOUNTING, FINANCE AND

MANAGEMENT SCIENCES

Vol. 10, No. 3, 2020, E-ISSN: 2225-8329 ๑ 2020 HRMARS

H6: Process is positively associated with customer satisfaction.

\section{Physical Evidence}

The final element to the three additional elements to the basic marketing mix is physical evidence (Booms \& Bitner, 1981). People and process have been previously presented and discussed, while physical evidence refers to the environment within which the service is delivered and where the firmcustomer interaction takes place for the facilitation of performance and service communication. Physical evidence therefore covers retail premises, bank branches, restaurants or hotel premises.

More importantly, the physical environment has to feel right to the customer/potential customer and be consistent with what they expect. In the past, bank staff had their positions behind glass screens when dealing with customers, which made them unapproachable. Slowly but surely, banks began to expose their staff to the public area for optimum customer interaction making the physical environment aligned with the marketing mix elements.

Furthermore, banks need physical evidence to relay the image of the service package to the customers (Miles, Miles \& Cannon, 2012). Banks may facilitate user-friendly, hi-tech and efficient image by ensuring comfortable seating, pleasant ambiance, efficient computer systems, advanced technology and network connectivity (Helm \& Gritsch, 2014). Both infrastructure and current technology impact the perceptions of the customers and their behavioral intentions (Kushwaha \& Agrawal, 2015) and thus, this study proposes that;

H7: Physical evidence is a positively associated with customer satisfaction.

\section{Customer Satisfaction and Customer Loyalty}

Customer satisfaction was deemed to be one of the major determinants of customer loyalty, which shows that every business needs to exert efforts to satisfy customers if they are desirous of obtaining their loyalty (Lin \& Wang, 2006). On this basis, Islamic banking has to attempt in delivering excellent services and develop good reputation to ensure customer satisfaction. Such satisfaction forms a mediating role on their loyalty to banks.

In the same line of study, Uncles, Dowling and Hammond (2003) referred to customer loyalty as the attitude that customers display to brands, services, product categories and stores. It is deemed as the relationship between the customers' relative attitude and their repetitive patronage (Dick \& Basu, 1994). Banks customer satisfaction and loyalty has been an ongoing field of research, with the belief that their success and competitiveness depend on new clients whereas their growth depends on the loyalty of their clients.

Customer loyalty concepts are divided into loyalty related to product, brand or organization and the concept arises with repetitive customer purchase of the same product/brand. Pritchard, Havitz and Howard (1999) described customer loyalty as having a crucial role in businesses, particularly in developing strategies and providing quality products and services to customers.

Majority of studies dedicated to this topic show marketing to have a significant association with product, price and customer loyalty dimensions, but not with place and promotion. In Wahab, Hassan, Shahid and Maon's (2016) study, the authors revealed the importance of customer satisfaction for customer loyalty. It is a crucial element for marketing mix that can assist business providers in providing customers what they need. Based on a few studies in literature (e.g., Al Muala, Al Qurneh \& Journal, 2012), product has a significant impact on customer loyalty, whereas pricing, personnel and processes have no effect. Thus, this study proposes the following hypothesis; 
INTERNATIONAL JOURNAL OF ACADEMIC RESEARCH IN ACCOUNTING, FINANCE AND

MANAGEMENT SCIENCES

Vol. 10, No. 3, 2020, E-ISSN: 2225-8329 @ 2020 HRMARS

H8: Customer satisfaction is positive associated with customer loyalty.

\section{Conceptual Framework}

The underpinning theories of this study are marketing mix (7Ps) theory and Customer Loyalty Theory.

\section{Theory of Service Marketing Mix (7Ps)}

Service Marketing Mix theory advocates a selection of developed services to offer customer choices of a specific range, with elements namely product, price, place, promotion, participants, physical evidence and process (Gibbs et al., 2008).

In the 7Ps, the definitions and indicators of individual variable have been adopted from many authors in literature. To begin with, product refers to a combination of goods/services offered by the firm to the target customers (Armstrong, Adam, Denize \& Kotler, 2014), while price refers to the amount that the consumer exchanges to purchase the offerings (Kushwaha \& Agrawal, 2015). Moving on to place, it is the distribution channel that is established to conduct economic societal functions, which bridges the production-consumption gap (Kotler, Armstrong, Wong \& Saunders, 2008). Moreover, promotion is the range of activities that firm marketers implement to promote the customers awareness of the products and to attract new customers' patronage (Singh, 2012). Physical evidence is described as the environment within which the service delivery takes place, the firm-customer interaction takes place and tangible components arise to facilitate the service performance and communication (Azila-Gbettor, Avorga, Danku \& Atatsi, 2013). Process concerns the firm's efforts to be customer-oriented and establish systematic procedures to achieve successful service delivery. It is reflected in the daily operations, mechanisms and flows of activities (Hapsari, Clemes \& Dean, 2017). Lastly, people refers to the key factor that can differentiate service marketing from physical product marketing and this covers main parameters to gauge the service marketing mix (Chaffey, 2019).

\section{Theory of Customer Loyalty}

Customer loyalty is described as the customer's commitment to repurchase or re-patronize a product/service in the future in the face of situational influences and marketing efforts that work towards bringing about switching behavior. Customer loyalty indicators are inclination towards repurchasing product/service over the long-haul, inclination to spread positive word-of-mouth, inclination to bring forward an idea for the company to create and develop a specific product (CossioSilva, Revilla-Camacho, Vega-Vazquez \& Palacios-Florencio, 2016; Hapsari et al., 2017).

This study primarily aims to determine if service marketing significantly affects customer loyalty and to determine which of the 7Ps have the highest impact on customer loyalty to Islamic banks in Jordan. 
INTERNATIONAL JOURNAL OF ACADEMIC RESEARCH IN ACCOUNTING, FINANCE AND MANAGEMENT SCIENCES

Vol. 10, No. 3, 2020, E-ISSN: 2225-8329 @ 2020 HRMARS

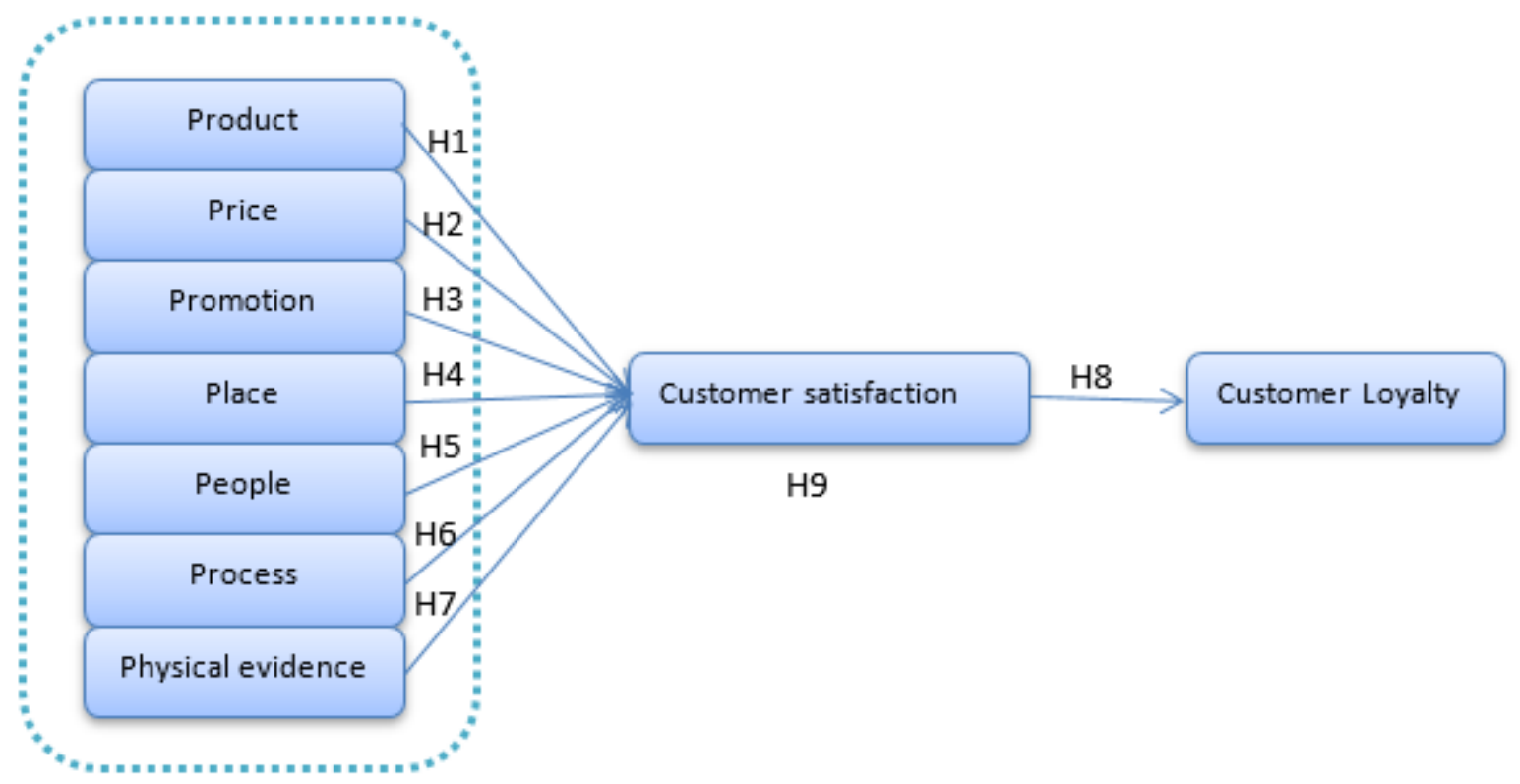

Figure 1: Conceptual Framework

The 7Ps are considered to be reflective of the firm strategy and as such, their combination can ultimately result in customer loyalty (Kasiri, Cheng, Sambasivan \& Sidin, 2017). Increased loyal customers will benefit the firm's long-term sustainability, whereas losing a single customer leads to significant losses. Thus, it can be argued that the variables of service marketing mix are significant to enhancing the firm's customer loyalty. This study proposes the following group of hypotheses;

H1:Product is positively associated with customer satisfaction.

H2: Price is positively associated with customer satisfaction.

H3: Promotion is positive associated with customer satisfaction.

H4: Place is positively associated with customer satisfaction.

H5: People are positively associated with customer satisfaction.

H6: Process is positively associated with customer satisfaction.

H7: Physical evidence is positively associated with customer satisfaction.

H8: Customer satisfaction is positively associated with customer loyalty.

H9: Customer satisfaction mediates the relationship between marketing mix and customer loyalty.

\section{Research Methodology}

This study focuses on the context of Jordanian Islamic banks. Therefore, the findings and the study itself are expected to assist Islamic financing sector investors as insight is provided into the customer loyalty towards Jordanian Islamic banks. The banking sector in Jordan is highly homogenized with regards to banking services. In relation to this, the service marketing mix comprises of seven Ps and they are product, price, place, promotion, process, people and physical evidence - these elements are considered as the study's independent variables to the dependent variable of customer loyalty (refer to Figure 1). The elements are examined as marketing mix elements and their relationship to customer satisfaction and ultimately loyalty. 
INTERNATIONAL JOURNAL OF ACADEMIC RESEARCH IN ACCOUNTING, FINANCE AND MANAGEMENT SCIENCES

Vol. 10, No. 3, 2020, E-ISSN: 2225-8329 @ 2020 HRMARS

\section{Measurements}

The primary instrument used for collecting data in this study is the survey questionnaire developed based on studies in literature dedicated to customer satisfaction and loyalty (refer to Table 1).

Table 1: Research measurements

\begin{tabular}{|c|c|c|c|}
\hline Contract & $\begin{array}{c}\text { No. } \\
\text { of } \\
\text { items }\end{array}$ & Observable variables & Reference \\
\hline Product & 2 & $\begin{array}{l}\text { 1. innovative products/services } \\
\text { 2. value added products/services }\end{array}$ & $\begin{array}{l}\text { Helm and Gritsch (2014); } \\
\text { (Kushwaha \& Agrawal, } \\
\text { 2015) }\end{array}$ \\
\hline Price & 2 & $\begin{array}{l}\text { 1. Low cost } \\
\text { 2. getting more }\end{array}$ & $\begin{array}{c}\text { Al-Dmour, Zu'bi, and } \\
\text { Kakeesh (2013); (Kushwaha } \\
\text { \& Agrawal, 2015) }\end{array}$ \\
\hline Promotion & 3 & $\begin{array}{l}\text { 1. bank advertisement } \\
\text { 2. social and cultural event } \\
\text { 3. promotional strategies impact }\end{array}$ & $\begin{array}{c}\text { Helm and Gritsch (2014); } \\
\text { (Kushwaha \& Agrawal, } \\
\text { 2015) }\end{array}$ \\
\hline Place & 2 & $\begin{array}{l}\text { 1. branch location convenience } \\
\text { 2. easy availability of ATM }\end{array}$ & $\begin{array}{l}\text { Helm and Gritsch (2014); } \\
\text { (Kushwaha \& Agrawal, } \\
\text { 2015) }\end{array}$ \\
\hline People & 4 & $\begin{array}{l}\text { 1. personal attention } \\
\text { 2. politeness } \\
\text { 3. willing to help } \\
\text { 4. quick response }\end{array}$ & $\begin{array}{c}\text { (Kushwaha \& Agrawal, } \\
\text { 2015; Lee, Lee, \& Park, } \\
\text { 2014) }\end{array}$ \\
\hline Process & 3 & $\begin{array}{l}\text { 1. easy and smooth } \\
\text { 2. fast online services } \\
\text { 3. services at your convenience }\end{array}$ & $\begin{array}{c}\text { (Kushwaha \& Agrawal, } \\
\text { 2015; Sreenivas, } \\
\text { Srinivasarao, Srinivasa Rao, } \\
\text { \& India, 2013) }\end{array}$ \\
\hline Physical & 2 & $\begin{array}{l}\text { 1. modern infrastructure } \\
\text { 2. advanced technology }\end{array}$ & $\begin{array}{l}\text { (Kushwaha \& Agrawal, } \\
\text { 2015; B. Othman et al., } \\
\text { 2019) }\end{array}$ \\
\hline $\begin{array}{l}\text { Customer } \\
\text { satisfaction }\end{array}$ & 2 & $\begin{array}{l}\text { 1. overall products/services quality } \\
\text { 2. safe and reliable }\end{array}$ & $\begin{array}{c}\text { (Kushwaha \& Agrawal, } \\
\text { 2015) } \\
\end{array}$ \\
\hline $\begin{array}{l}\text { customer } \\
\text { loyalty }\end{array}$ & 3 & $\begin{array}{l}\text { 1. willingness to keep buying the } \\
\text { product/service over a long time } \\
\text { 2. willingness to do positive word-of } \\
\text { mouth, } \\
\text { 3. willingness to propose an idea for } \\
\text { the bank to develop the product }\end{array}$ & (Rai \& Srivastava, 2012) \\
\hline
\end{tabular}

The survey contains 23 items adopted and adapted from literature to be consistent with the study objectives. The survey was developed in English and was later translated into Arabic to cater to the Arab speaking respondents. The respondents were requested to answer the items using a five-point 
INTERNATIONAL JOURNAL OF ACADEMIC RESEARCH IN ACCOUNTING, FINANCE AND MANAGEMENT SCIENCES

Vol. 10 , No. 3, 2020, E-ISSN: $2225-8329$ (c) 2020 HRMARS

Likert scale that ranged from 1 depicting strongly disagree to 5 depicting strongly agree. The items were obtained from literature of IS studies, in that their validity and reliability have already been established. The construct validity of the questionnaire was confirmed by confirming the level to which the measurement items correspond to their variables. The validity of the survey items was also confirmed through literature review and the assessment of the original studies.

\section{Data Collection}

This quantitative research employed convenience method to collect the required data from a total of 344 respondents, who were customers of Islamic banks, and had experienced their services. A selfadministered questionnaire was used to collect data for the achievement of the objectives, the determination of the answers to the research questions and the testing of hypotheses. The selfdelivery and collection questionnaire copies were the most appropriate method to obtain high response rate from the respondents. A total of 450 questionnaire copies were personally distributed to the respondents, from which $76.4 \%$ rate of response were achieved (106 incomplete questionnaires). Majority of the respondents (77\%) were aged 40 and below, they were of male gender (86.0\%), holding bachelor degrees (66\%).

\section{Data Analysis}

The PLS-SEM technique was adopted for analysis with Smart PLS Version 3.0. PLS in SEM analyzes the structural measurement of the model and the associated paths. The method provides factor loadings, which are the same with principal component analysis (refer to Sosik, Kahai \& Piovoso, 2009). Using PLS allows the author to investigate and analyze the research model's validity and the empirical model's relationships in terms of their significance. Hair, Ringle and Sarstedt (2013) explained that PLS is beneficial to us over other methods of structural modeling as it allows examination of variables that are distributed in a non-normal manner. PLS also works for estimations of path models and it is suitable for small-sized samples and for complex research models (Byrne, 2001). PLS is also suitable for exploratory studies like the present study as the studies dedicated to service marketing mix influence on customer loyalty are still few and far between.

\section{Results}

\section{Measurement Model}

For the measurement model, the study confirmed construct reliability by observing the loadings of items and the composite reliability values. Individual item reliability relates to their loadings - in this regard, loadings should be 0.7 or over according to Hair Jr., Hult, Ringle and Sarstedt (2016), but others like Hulland (1999) contended that some items may have lower loadings, especially in case of novel constructed scales or available ones that were shifted and examined in a different situation. Hair Jr. et al. (2016) explained that loadings that fall in the range from 0.40 to 0.70 should be dropped if their dropping would increase the AVE or the composite reliability values.

Hair et al. (2016) further stated that in PLS-SEM, using composite reliability score is suitable to ensure construct reliability albeit some other common measure of internal consistency exists like Cronbach's alpha. This is because the former never pre-supposes the equal reliability of all indictors unlike Cronbach's alpha. Cronbach's alpha is also sensitive to the number of items in a scale (Hair Jr., et al., 2016). On the basis of the values in Table 2, latent variables composite reliability all exceeded the 0.70 threshold. 
INTERNATIONAL JOURNAL OF ACADEMIC RESEARCH IN ACCOUNTING, FINANCE AND MANAGEMENT SCIENCES

Vol. 10, No. 3, 2020, E-ISSN: 2225-8329 @ 2020 HRMARS

Moving on to convergent validity, the AVE was used in this study, with the premise that values higher than 0.5 are acceptable (Hair Jr., et al., 2016). The study found the lowest AVE to be 0.65 , indicating that the constructs requirements were satisfied and the internal consistency of the constructs is sufficient.

Table 2: Measurement model

\begin{tabular}{cllccc}
\hline Construct & Items & Loadings & CR & $\begin{array}{c}\text { C. } \\
\text { Alpha }\end{array}$ & AVE \\
& & & & & \\
\hline Product & PROD-1 & 0.928 & $\mathbf{0 . 9 2 2}$ & $\mathbf{0 . 8 3 1}$ & $\mathbf{0 . 8 5 5}$ \\
& PROD-2 & 0.922 & & & \\
\hline Price & PR-1 & 0.902 & $\mathbf{0 . 9 0 5}$ & $\mathbf{0 . 7 9 1}$ & $\mathbf{0 . 8 2 7}$ \\
& PR-2 & 0.917 & & & \\
\hline Promotion & PROM-1 & 0.832 & $\mathbf{0 . 8 4 9}$ & $\mathbf{0 . 7 3 5}$ & $\mathbf{0 . 6 5 3}$ \\
& PROM-2 & 0.796 & & & \\
& PROM-3 & 0.796 & & & \\
\hline Place & PL-1 & 0.892 & $\mathbf{0 . 8 9 3}$ & $\mathbf{0 . 7 6 0}$ & $\mathbf{0 . 8 0 6}$ \\
& PL-2 & 0.904 & & & \\
\hline People & PE-1 & 0.857 & $\mathbf{0 . 9 3 2}$ & $\mathbf{0 . 9 0 3}$ & $\mathbf{0 . 7 7 5}$ \\
& PE-2 & 0.891 & & & \\
& PE-3 & 0.895 & & & \\
\hline & PE-4 & 0.878 & & & \\
\hline Process & PRO-1 & 0.909 & $\mathbf{0 . 9 2 5}$ & $\mathbf{0 . 8 7 8}$ & $\mathbf{0 . 8 0 4}$ \\
& PRO-2 & 0.895 & & & \\
& PRO-3 & 0.885 & & & \\
\hline Physical & PH-1 & 0.860 & $\mathbf{0 . 8 5 2}$ & $\mathbf{0 . 7 6 2}$ & $\mathbf{0 . 7 4 2}$ \\
& PH-2 & 0.863 & & & \\
\hline Customer satisfaction & C.S-1 & 0.932 & $\mathbf{0 . 9 2 7}$ & $\mathbf{0 . 8 4 4}$ & $\mathbf{0 . 8 6 5}$ \\
& C.S-2 & 0.928 & & & \\
\hline C.L-1 & 0.914 & $\mathbf{0 . 9 1 8}$ & $\mathbf{0 . 8 6 6}$ & $\mathbf{0 . 7 8 8}$ \\
& C.L-2 & 0.887 & & & \\
\hline & C.L-3 & 0.862 & & & \\
\hline & & & & & \\
\hline
\end{tabular}

The study also tested for discriminant validity, which is the level to which empirical conditions actually differentiate a construct from the others (Hair Jr., et al., 2016). Through the confirmation of discriminate validity, the construct can be considered as distinct and unique and this approach is required as it steers clear of overlapping constructs, where model constructs may not accurately reflect the examined phenomenon (Hair Jr. et al., 2016). Thus, the present study adopted two discriminant validity measures recommended by Hair Jr. et al. (2016), which are cross-loading of indicators and Fornell-Larcker's criterion of discriminant validity assessment. In Table 3, it is evident that the construct indicators outer loadings exceeded the cross-loads with other constructs, confirming discriminant validity. 
INTERNATIONAL JOURNAL OF ACADEMIC RESEARCH IN ACCOUNTING, FINANCE AND MANAGEMENT SCIENCES

Vol. 10, No. 3, 2020, E-ISSN: 2225-8329 @ 2020 HRMARS

Table 3: Discriminant validity

\begin{tabular}{|c|c|c|c|c|c|c|c|c|c|}
\hline & $\begin{array}{l}\text { custome } \\
\text { r loyalty }\end{array}$ & $\begin{array}{l}\text { Customer } \\
\text { satisfacti } \\
\text { on }\end{array}$ & $\begin{array}{l}\text { Peopl } \\
\text { e }\end{array}$ & $\begin{array}{c}\text { Physica } \\
\text { I } \\
\text { Evidenc } \\
\text { e } \\
\end{array}$ & $\begin{array}{c}\text { Plac } \\
\text { e }\end{array}$ & $\begin{array}{c}\text { Pric } \\
\text { e }\end{array}$ & $\begin{array}{c}\text { Proces } \\
\text { s }\end{array}$ & $\begin{array}{l}\text { Produ } \\
\text { ct }\end{array}$ & $\begin{array}{c}\text { Promotio } \\
\mathbf{n}\end{array}$ \\
\hline $\begin{array}{c}\text { customer } \\
\text { loyalty }\end{array}$ & 0.888 & & & & & & & & \\
\hline $\begin{array}{l}\text { Customer } \\
\text { satisfacti } \\
\text { on }\end{array}$ & 0.332 & 0.930 & & & & & & & \\
\hline People & 0.302 & 0.749 & 0.880 & & & & & & \\
\hline $\begin{array}{l}\text { Physical } \\
\text { Evidence }\end{array}$ & 0.258 & 0.642 & 0.603 & 0.861 & & & & & \\
\hline Place & 0.300 & 0.707 & 0.767 & 0.562 & $\begin{array}{c}0.89 \\
8\end{array}$ & & & & \\
\hline Price & 0.400 & 0.756 & 0.741 & 0.571 & $\begin{array}{c}0.73 \\
1 \\
\end{array}$ & $\begin{array}{c}0.90 \\
9\end{array}$ & & & \\
\hline Process & 0.348 & 0.742 & 0.789 & 0.601 & $\begin{array}{c}0.74 \\
5 \\
\end{array}$ & $\begin{array}{c}0.74 \\
1 \\
\end{array}$ & 0.897 & & \\
\hline Product & 0.355 & 0.747 & 0.751 & 0.555 & $\begin{array}{c}0.75 \\
6 \\
\end{array}$ & $\begin{array}{c}0.78 \\
1 \\
\end{array}$ & 0.756 & 0.925 & \\
\hline $\begin{array}{c}\text { Promotio } \\
n\end{array}$ & 0.275 & 0.600 & 0.528 & 0.637 & $\begin{array}{c}0.49 \\
6\end{array}$ & $\begin{array}{c}0.49 \\
6\end{array}$ & 0.531 & 0.500 & 0.808 \\
\hline
\end{tabular}

\section{Structural Model}

This study conducted an evaluation of the structural model using $\mathrm{R}^{2}$ values of the dependent variable, which were obtained as follows; customer loyalty (0.106) and customer satisfaction (0.821). Both values exceed the thresholds set down by Hair Jr. et al. (2016) and they seem to correspond to the PLS values in prior studies (e.g., Al Shbail, Salleh \& Nor, 2018; Shbail, Salleh \& Mohd Nor, 2018). Following Hair Jr. et al.'s (2016) suggestion, the study based the coefficients significance on 5000 bootstrapping samples. The results of hypotheses testing are presented in Table 4. 
INTERNATIONAL JOURNAL OF ACADEMIC RESEARCH IN ACCOUNTING, FINANCE AND MANAGEMENT SCIENCES

Vol. 10, No. 3, 2020, E-ISSN: 2225-8329 ๔ 2020 HRMARS

Table 4: Structural model results

\begin{tabular}{|c|c|c|c|c|c|c|}
\hline Hypothesis & Path & & $\begin{array}{l}\text { Original } \\
\text { Sample } \\
\text { (O) }\end{array}$ & $\begin{array}{lr}\text { T } & \text { Statistics } \\
(|\mathrm{O} / \mathrm{STDEV}|)\end{array}$ & $\begin{array}{l}\mathbf{P} \\
\text { Values }\end{array}$ & Decision \\
\hline $\mathrm{H} 1$ & Product $\rightarrow$ C.S & & 0.194 & 2.421 & 0.016 & Supported \\
\hline $\mathrm{H} 2$ & Price -> C.S & & 0.292 & 3.836 & 0.000 & Supported \\
\hline $\mathrm{H3}$ & Promotion -> C.S & & 0.126 & 3.752 & 0.000 & Supported \\
\hline $\mathrm{H} 4$ & Place -> C.S & & 0.102 & 2.031 & 0.045 & Supported \\
\hline $\mathrm{H} 5$ & People -> C.S & & 0.205 & 2.641 & 0.009 & Supported \\
\hline $\mathrm{H} 6$ & Process $->$ C.S & & 0.227 & 3.400 & 0.002 & Supported \\
\hline $\mathrm{H7}$ & Physical Evidence -> C.S & & 0.185 & 2.049 & 0.041 & Supported \\
\hline $\mathrm{H} 8$ & $\begin{array}{l}\text { Customer Satisfaction } \\
\text { Customer loyalty }\end{array}$ & $->$ & 0.332 & 4.371 & 0.000 & Supported \\
\hline $\mathrm{H} 9$ & Marketing mix $->$ C.S $->$ C.L & & 0.301 & 3.933 & 0.000 & Supported \\
\hline
\end{tabular}

From the table results, it is evident that $\mathrm{H} 1$ proposition of the positive effect of product on customer satisfaction is supported $(\beta=0.194, t=2.421, p<0.05)$, and is consistent with those reported by Sathiyavany and Shivany (2018). With regards to price in $\mathrm{H} 2$, it was also found to have a positive effect on customer satisfaction $(\beta=0.292, t=3.836, p<0.05)$, supporting the hypothesis and supporting the findings of the study reported by Kushwaha and Agrawal (2015). In H3, promotion was hypothesized to significantly associate with customer satisfaction and based on the result $(\beta=$ $0.126, t=3.752, p<0.05)$, the hypothesis is supported. Similarly, place in $\mathrm{H} 4$ was also found to have a positive association with customer satisfaction $(\beta=0.102, t=2.031, p<0.05)$, indicating support for the hypothesis. Moving on to people hypothesized in $\mathrm{H} 5$ as having a significant relationship with customer satisfaction, the results supports the hypothesis $(\beta=0.205, t=2.641, p<0.05)$. Along the same line of positive association, $\mathrm{H} 6$ also has a significant relationship with customer satisfaction ( $\beta$ $=0.227, t=3.400, p<0.05)$ and so does physical evidence in $\mathrm{H7}(\beta=0.185, t=2.049, p<0.05)$, which indicates that both hypotheses are supported. In $\mathrm{H} 8$, it was hypothesized that customer satisfaction has a significant positive association with customer loyalty, and from the results $(\beta=0.332, t=4.371$, $p<0.05)$, it is clear that the hypothesis is supported. Finally, customer satisfaction appeared to play a significant mediating role on the marketing mix-customer loyalty relationship $(\beta=0.301, t=3.933, p$ $<0.05)$, supporting $\mathrm{H} 9$.

\section{Conclusion}

This research aimed to propose and develop a conceptual model to explain the effect of service marketing mix on customer loyalty, and to validate the model and confirm its structure in the context of Islamic banks in Jordan. The analysis of validity and reliability revealed scores confirming both. The results also confirmed the mediating role of customer satisfaction on the marketing mix-customer loyalty relationship. The study findings provide empirical evidence supporting the key role of marketing mix and customer satisfaction in achieving the loyalty of customers. This study also has practical implications for manager and practitioner circles, providing them the knowledge and information to develop and create service marketing and highlighting the significance of both marketing mix and customer satisfaction to obtain the customers' loyalty to banking institutions. 
INTERNATIONAL JOURNAL OF ACADEMIC RESEARCH IN ACCOUNTING, FINANCE AND

MANAGEMENT SCIENCES

Vol. 10, No. 3, 2020, E-ISSN: 2225-8329 @ 2020 HRMARS

Banks management may also leverage the findings to determine the marketing mix factors that hold topmost importance to obtaining customer loyalty.

\section{Limitation and Future Studies}

According to the research findings, it is crucial to measure and examine marketing mix to obtain customer loyalty towards Islamic banks with the help of customer satisfaction as the mediating variable. This study suggests that future studies should focus on the relationship between marketing mix and customer loyalty in different domains. Future studies may also include other factors that were excluded from this study and conduct comparisons of findings, using other methods other than survey questionnaire in other industries.

\section{References}

Al-Dmour, H., Zu'bi, M., \& Kakeesh, D. (2013). The effect of services marketing mix elements on customer-based brand equity: An empirical study on mobile telecom service recipients in Jordan. International Journal of Business and Management, 8(11), 13.

Al Muala, A., Al Qurneh, M. J. A. A., \& journal, S. R. (2012). Assessing the relationship between marketing mix and loyalty through tourists satisfaction in Jordan curative tourism. 4(2), 1.

Al Shbail, M. O., Salleh, Z., \& Nor, M. N. M. (2018). The effect of ethical tension and time pressure on job burnout and premature sign-off. Journal of Business Retail Management Research, 12(4), 43-53. doi:https://doi.org/10.24052/JBRMR/V12IS04/ART-05

AMEUR, I., Keltouma, M., \& SOUAR, Y. J. E. J. O. M. (2015). The impact of marketing mix elements on customer loyalty for an Algerian telecommunication company. 3(1).

Armstrong, G., Adam, S., Denize, S., \& Kotler, P. (2014). Principles of marketing: Pearson Australia.

Azila-Gbettor, E. M., Avorga, S. M. K., Danku, L. S., \& Atatsi, E. A. (2013). Physical evidence and quality service delivery in public hospitals in Ghana. International Review of Management and Marketing, 3(4), 153-163.

Booms, B. H., \& Bitner, M. J. J. A. O. T. R. (1980). New management tools for the successful tourism manager. 7(3), 337-352.

Byrne, B. M. (2001). Structural Equation Modeling With AMOS, EQS, and LISREL: Comparative Approaches to Testing for the Factorial Validity of a Measuring Instrument. International Journal of Testing, 1(1), 55-86. doi:https://doi.org/10.1207/S15327574IJT0101_4

Central_Bank_of_Jordan. (2019). Guide banks in Jordan. Retrieved from http://www.cbj.gov.jo/Pages/viewpage.aspx?pagelD=307

Chaffey, D. (2019). Digital marketing: Pearson UK.

Cossío-Silva, F.-J., Revilla-Camacho, M.-Á., Vega-Vázquez, M., \& Palacios-Florencio, B. (2016). Value co-creation and customer loyalty. Journal of Business Research, 69(5), 1621-1625.

Di Bella, V., \& Al-Fayoumi, N. (2016). Perception of stakeholders on corporate social responsibility of Islamic Banks in Jordan. EuroMed Journal of Business.

Dick, A. S., \& Basu, K. J. J. O. T. A. O. M. S. (1994). Customer loyalty: toward an integrated conceptual framework. 22(2), 99-113.

Fukey, L. N., Issac, S. S., Balasubramanian, K., \& Jaykumar, V. (2014). Service delivery quality improvement models: a review. Procedia-Social and Behavioral Sciences, 144, 343-359.

Gibbs, P., Pashiardis, P., \& Ivy, J. (2008). A new higher education marketing mix: the 7Ps for MBA marketing. International Journal of educational management. 
INTERNATIONAL JOURNAL OF ACADEMIC RESEARCH IN ACCOUNTING, FINANCE AND

MANAGEMENT SCIENCES

Vol. 10, No. 3, 2020, E-ISSN: 2225-8329 ๑ 2020 HRMARS

Hair, J. F., Ringle, C. M., \& Sarstedt, M. (2013). Editorial - Partial Least Squares Structural Equation Modeling: Rigorous Applications, Better Results and Higher Acceptance. Econometrics:

Multiple Equation Models eJournal, 6, 1-12. doi:10.1016/j.Irp.2013.01.001

Hair Jr, J. F., Hult, G. T. M., Ringle, C., \& Sarstedt, M. (2016). A primer on partial least squares structural equation modeling (PLS-SEM): Sage publications.

Hapsari, R., Clemes, M. D., \& Dean, D. (2017). The impact of service quality, customer engagement and selected marketing constructs on airline passenger loyalty. International Journal of Quality and Service Sciences.

Helm, R., \& Gritsch, S. (2014). Examining the influence of uncertainty on marketing mix strategy elements in emerging business to business export-markets. International Business Review, 23(2), 418-428.

Hoffmann, A. O., \& Birnbrich, C. (2012). The impact of fraud prevention on bank-customer relationships. International journal of bank marketing.

Hulland, J. (1999). Use of partial least squares (PLS) in strategic management research: a review of four recent studies. Strategic management journal, 20(2), 195-204. doi:10.1002/(sici)10970266(199902)20:2<195::Aid-smj13>3.0.Co;2-7

Judd, V. (1987). Differentiate with the 5th P: People. Industrial Marketing Management, 16(4), 241247.

Kasiri, L. A., Cheng, K. T. G., Sambasivan, M., \& Sidin, S. M. (2017). Integration of standardization and customization: Impact on service quality, customer satisfaction, and loyalty. Journal of Retailing and consumer services, 35, 91-97.

Kotler, P., Armstrong, G., Wong, V., \& Saunders, J. (2008). Marketing defined. Principles of marketing, 7.

Kotler, P., Burton, S., Deans, K., Brown, L., \& Armstrong, G. (2015). Marketing. AU: Pearson Higher Education.

Kushwaha, G. S., \& Agrawal, S. R. (2015). An Indian customer surrounding 7P's of service marketing. Journal of Retailing and consumer services, 22, 85-95. doi:https://doi.org/10.1016/j.jretconser.2014.10.006

Lee, J.-S., Lee, C.-K., \& Park, C.-K. (2014). Developing and validating a multidimensional quality scale for mega-events. International journal of hospitality management, 43, 121-131.

Lin, H.-H., \& Wang, Y.-S. (2006). An examination of the determinants of customer loyalty in mobile commerce contexts. Information management Science Letters, 43(3), 271-282.

Mandal, P. C. (2020). Achieving excellence in services marketing: roles in customer delight. International Journal of Business Excellence, 20(3), 359-374.

Miles, P., Miles, G., \& Cannon, A. (2012). Linking servicescape to customer satisfaction: exploring the role of competitive strategy. International Journal of Operations \& Production Management.

Mohammad, H. I. (2015). 7PS marketing mix and retail bank customer satisfaction in northeast Nigeria. British journal of marketing studies, 3(3), 71-88.

Othman, B., Harun, A., Rashid, W., Nazeer, S., Kassim, A., \& Kadhim, K. (2019). The influences of service marketing mix on customer loyalty towards Umrah travel agents: Evidence from Malaysia. Management Science Letters, 9(6), 865-876. 
INTERNATIONAL JOURNAL OF ACADEMIC RESEARCH IN ACCOUNTING, FINANCE AND

MANAGEMENT SCIENCES

Vol. 10, No. 3, 2020, E-ISSN: 2225-8329 @ 2020 HRMARS

Othman, B. A., Harun, A. B., \& Nazeer, S. (2018). Issues and challenges faced by Malaysian umrah travel Agencies in providing excellent marketing mix services to umrah pilgrims. The Journal of Social Sciences Research, 611-618: 612.

Owomoyela, S., Oyeniyi, K., \& Ola, O. (2013). Investigating the impact of marketing mix elements on consumer loyalty: An empirical study on Nigerian Breweries Plc. Interdisciplinary journal of contemporary research in business, 4(11), 485-496.

Payne, A., Frow, P., \& Eggert, A. (2017). The customer value proposition: evolution, development, and application in marketing. Journal of the Academy of Marketing Science, 45(4), 467-489.

Pritchard, M. P., Havitz, M. E., \& Howard, D. (1999). Analyzing the commitment-loyalty link in service contexts. Journal of the Academy of Marketing Science, 27(3), 333.

Rai, A. K., \& Srivastava, M. (2012). Customer loyalty attributes: A perspective. NMIMS management review, 22(3), 49-76.

Sathiyavany, N., \& Shivany, S. (2018). E-Banking Service Qualities, E-Customer Satisfaction, and eLoyalty: A conceptual Model. The International Journal of Social Sciences and Humanities Invention, 5(6), 4808-4819.

Shamah, R. A. (2013). A model for applying lean thinking to value creation. International journal of lean six sigma.

Singh, M. (2012). Marketing mix of 4P's for competitive advantage. IOSR Journal of Business and Management, 3(6), 40-45.

SI Shbail, M., Salleh, Z., \& Nor, M. N. N. (2018). Antecedents of burnout and its relationship to internal audit quality. Business and Economic Horizons (BEH), 14(4), 789-817. doi:https://doi.org/10.22004/ag.econ.287230

Sosik, J. J., Kahai, S. S., \& Piovoso, M. J. (2009). Silver Bullet or Voodoo Statistics?: A Primer for Using the Partial Least Squares Data Analytic Technique in Group and Organization Research. Group \& Organization Management, 34(1), 5-36. doi:10.1177/1059601108329198

Sreenivas, T., Srinivasarao, B., Rao, S. U., \& India, A. (2013). An analysis on marketing mix in hospitals. International Journal of Advanced Research in Management and Social Sciences, 2(4), 187-207.

Uncles, M. D., Dowling, G. R., \& Hammond, K. (2003). Customer loyalty and customer loyalty programs. Journal of consumer marketing.

Van Waterschoot, W., \& Van den Bulte, C. (1992). The 4P classification of the marketing mix revisited. Journal of marketing, 56(4), 83-93.

Varki, S., \& Colgate, M. (2001). The role of price perceptions in an integrated model of behavioral intentions. Journal of Service Research, 3(3), 232-240.

Wahab, N. A., Hassan, L. F. A., Shahid, S. A. M., \& Maon, S. N. (2016). The relationship between marketing mix and customer loyalty in hijab industry: The mediating effect of customer satisfaction. Procedia Economics Finance, 37(16), 366-371.

Wang, S., Hu, Q., \& Liu, W. (2017). Price and quality-based competition and channel structure with consumer loyalty. European Journal of Operational Research, 262(2), 563-574.

Wolter, J. S., Bock, D., Smith, J. S., \& Cronin Jr, J. J. (2017). Creating ultimate customer loyalty through loyalty conviction and customer-company identification. Journal of Retailing, 93(4), 458-476.

Yelkur, R. (2000). Customer satisfaction and the services marketing mix. Journal of professional services marketing, 21(1), 105-115. 